\title{
PRELIMINARY IDENTIFICATION AND QUANTIFICATION OF THE AGE-PIGMENT LIPOFUSCIN IN THE BRAIN OF Farfantepenaeus paulensis (CRUSTACEA: DECAPODA)
}

\author{
PEIXOTO, S., ${ }^{1}$ AGUADO, N., ${ }^{1}$ D'INCAO, F., ${ }^{1}$ WASIELESKY, W. ${ }^{1}$ and COUSIN, J. C. ${ }^{2}$ \\ ${ }^{1}$ Departamento de Oceanografia, Fundação Universidade Federal do Rio Grande, \\ C. P. 474, CEP 96201-900, Rio Grande, RS, Brazil \\ ${ }^{2}$ Departamento de Ciências Morfo-Biológicas, Fundação Universidade Federal do Rio Grande, \\ C. P. 474, CEP 96201-900, Rio Grande, RS, Brazil \\ Correspondence to: Sílvio Peixoto, Dep. de Oceanografia, Lab. de Aquacultura, Fundação Universidade Federal do \\ Rio Grande, C. P. 474, CEP 96201-900, Rio Grande, RS, Brazil, e-mail: silviop@ mikeus.com.br \\ Received September 11, 2001 - Accepted January 29, 2002 - Distributed November 30, 2002
}

(With 3 figures)

\begin{abstract}
A preliminary study was done on the age-pigment lipofuscin content in the brains of captive Farfantepenaeus paulensis juveniles (5 months old) and wild adults (estimated age of 12-15 months). Random samples of 6 individuals were obtained from each group (juvenile and adult) for histological analysis. Serial sections $(6 \mu \mathrm{m})$ of the brains were mounted without staining and observed in an epifluorescent microscope. The fluorescent images of the five most central sections of the olfactory lobe cell mass (OLCM) of each individual were digitized for image analysis. The lipofuscin granule mean diameter was similar in both groups $(\mathrm{p}>0.05)$, however the lipofuscin area fraction (percentage of the OLCM occupied by pigment granules) was significantly higher $(\mathrm{p}<0.05)$ in the adult shrimp. The detection of lipofuscin granules in 5 month old $F$. paulensis indicates that lipofuscin deposition probably takes place even earlier in the juvenile phase. Our results suggested that the amount of granules in the F. paulensis OLCM is related to age, but further studies are necessary to evaluate the relationship between lipofuscin content and the age of captive $F$. paulensis.
\end{abstract}

Key words: lipofuscin, age-pigment, penaeid, F. paulensis.

\section{RESUMO}

Identificação e quantificação preliminar do pigmento da idade, lipofuscina, em cérebros de Farfantepenaeus paulensis (Crustacea: Decapoda)

Foi realizada análise preliminar do conteúdo de lipofuscina em cérebros de juvenis de Farfantepenaeus paulensis oriundos de cativeiro (5 meses de idade) e de adultos selvagens (idade estimada de 12 15 meses). Foram coletadas amostras aleatórias de 6 indivíduos de cada grupo (juvenis e adultos) para análises histológicas. Cortes frontais $(6 \mu \mathrm{m})$ dos cérebros foram montados em lâminas, sem serem corados, e observados em microscópio de epifluorescência. As imagens fluorescentes dos 5 cortes mais centrais da massa de células do lóbulo olfatório (MCLO) de cada indivíduo foram digitalizadas para posterior análise de imagens. O diâmetro médio dos grânulos de lipofuscina foram similares entre os dois grupos ( $p>0,05)$, entretanto, a porcentagem da área de MCLO ocupada por grânulos foi significativamente maior $(\mathrm{p}<0,05)$ nos camarões adultos. A detecção de grânulos de lipofuscina em $F$. paulensis com 5 meses de idade indica a possibilidade de o início de deposição ocorrer anteriormente em juvenis. Os resultados sugerem que a quantidade de grânulos na MCLO de $F$. paulensis está relacionada à idade, contudo, futuros estudos são necessários para avaliar a relação entre a quantidade de lipofuscina e a idade de $F$. paulensis mantidos em cativeiro.

Palavras-chave: cipofuscina, pigmento, idade, peneídeo, F. paulensis. 


\section{INTRODUCTION}

Penaeid shrimp show discontinuous growth pattern (molts separated by intermolt periods) and bony structures are absent; as a consequence, traditional age determination methods cannot be applied (Garcia \& Le Reste, 1981). Thus, modal progression analysis of body or carapace length is generally used to estimate age.

The von Bertalanffy growth model, although proposed within physiological fish concepts, appropriately describes crustacean growth (Garcia \& Le Reste, 1981; Rothlisberg, 1998). However, a wide variation in asymptotic length and longevity estimations has been reported, even within species, when von Bertalanffy's model was applied to penaeids (D'Incao \& Fonseca, 1998).

More reliable age determination methods have been proposed which rely on quantitative studies of the age-pigment lipofuscin concentration in crustacean brains (Sheehy, 1989, 1990; Wahle et al., 1996). Lipofuscin is produced in secondary lysossomes as a result of non-dividing cell metabolism (Dowson \& Harris, 1981). Lipofuscin granules can be found in eyestalk ganglia and all crustacean brain regions. However, more conspicuous concentrations are related with the olfactory lobe cell masses (OLCM) (Sheehy, 1990; Belchier et al., 1994). The emission of yellowto-greenish fluorescence when lipofuscin granules are excited with ultraviolet and blue light has been successfully used to quantify them on histological sections of nervous tissue (Sheehy, 1989; Hill \& Womersley, 1991).

In spite of the applicability of this reliable age-estimation method in many crustacean species, specifically in penaeids, few studies have reported the identification and quantification of lipofuscin granules in nervous tissues (Sheehy et al., 1995; Ramos et al., 1998; Medina et al., 2000; Vila et al., 2000). Thus, the present research was proposed to verify the presence and concentration of lipofuscin in two different age classes of Farfantepenaeus paulensis.

\section{MATERIAL AND METHODS}

\section{Biological samples}

The lipofuscin content was determined in two groups based on different age/size classes. In the adult group, wild $F$. paulensis broodstock were trawled in shallow coastal waters (5-15 m) of Florianópolis
North Bay (Santa Catarina, Brazil) and were maintained under reproductive laboratory conditions (Marchiori, 1996; Cavalli et al., 1997) during 5 months. Broodstock age was estimated at between 12 and 15 months, based on the weight growth curve described in a previous study (Peixoto et al., 2000).

In the juvenile group, a single stock of $F$. paulensis larvae hatched on December 15, 2000, was obtained at the Marine Aquaculture Station, University of Rio Grande, Rio Grande do Sul State, Brazil. Afterward, they were reared for 4 months in pen culture at the Patos Lagoon Estuary (Rio Grande do Sul, Brazil), at a density of 10 shrimp/ $\mathrm{m}^{2}$ and fed on a commercial shrimp diet (Purina ${ }^{\circledR}$ with $35 \%$ of protein content). Mean temperature and salinity were $24^{\circ} \mathrm{C}$ and 6 , respectively. Juveniles were 5 months old when sampled.

\section{Histological analysis}

Random samples of 6 individuals were analysed from each group (adult and juvenile). Shrimps had their carapace length and weight recorded. Icy sea water was used to immobilize the individuals before each cephalotorax was cut out (at the first pereiopod pair base) and fixed for 20 days in $10 \%$ formol saline.

The brains were carefully dissected (supraoesophageal ganglion) and weighed. All nerves originating from the brain were removed, excepted for the circunoesophageal commissure, to facilitate handling and orientation in paraffin wax (Fig. 1). Brains were subsequently dehydrated in increasing ethanol concentrations (15 minutes each), transferred to two xylene baths (5 minutes in each), and embedded in paraffin wax on the vertical plane with the supra-oesophageal ganglion facing the cutting edge of the wax block.

Serial sections $(6 \mu \mathrm{m})$ of the brains were dewaxed through two xylene changes (15 minutes in each) and unstained sections were mounted. Control sections used for OLCM localization were stained with hematoxylin-eosin.

Identification and quantification of lipofuscin Autofluorescence of unstained sections was observed with an epifluorescent microscope equipped with a 50W mercury lamp and a 450-490 nm excitation filter. The fluorescent image, at a magnification of 400x, was captured by video camera and digitized. Images of the five most central sections of each OLCM were used for image analysis. 


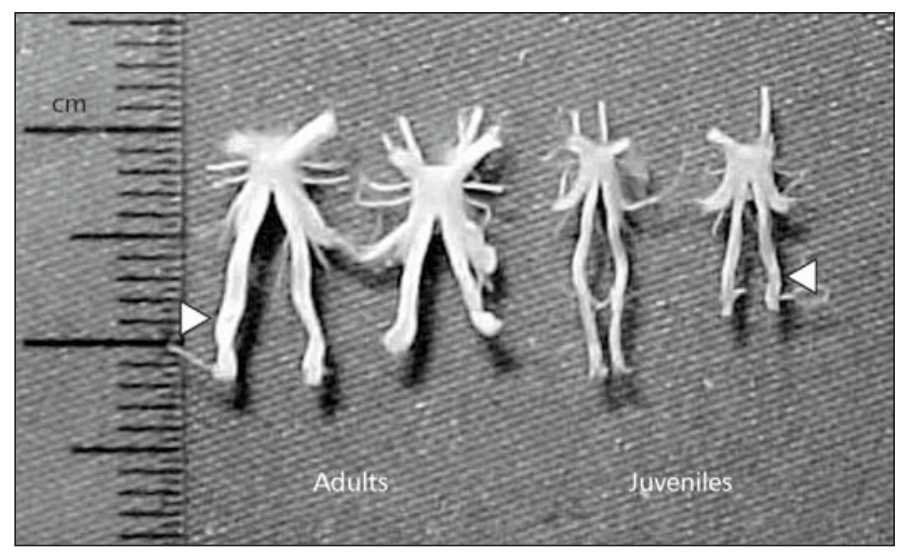

Fig. 1 - Brains removed from Farfantepenaeus paulensis adults and juveniles. Only the circunoesophageal commissure (arrowheads) was kept to facilitate handling and vertical orientation in the paraffin wax.

After determination of the proper grey-scale levels, edited binary images of the brightly fluorescent lipofuscin granules were quantified using ImageTools ${ }^{\circledR}$ software. Two measurements of lipofuscin amounts were recorded for every image: the lipofuscin area fraction (percentage of the OLCM occupied by pigment granules) and the mean lipofuscin granule diameter.

The Student's t-test was used to detect differences at 0.05 significance level between the shrimp measurements and lipofuscin quantification in the two groups. Percentage data (e.g. lipofuscin area fraction) were arcsine transformed for analysis, but only untransformed values are presented.

\section{RESULTS}

Globuli cell masses were easily identifiable by their fan shape and central fiber tract penetrating into the ventral portion of each olfactory lobe. Due to their high affinity for morphological stains, the OLCMs were easily detectable in the control sections stained with hematoxylin-eosin (Fig. 2).

Epifluorescence microscopy allowed distinguishing the brightly fluorescent lipofuscin granules from the less intense background of the OLCM. In this way, presence of lipofuscin granules was observed to be more conspicuous in larger/older shrimp (Fig. 3).

The mean diameter of lipofuscin granules was similar in both groups $(\mathrm{p}>0.05)$, however, the lipofuscin area fraction was significantly higher $(\mathrm{p}<0.05)$ in the adult shrimp (Table 1). Moreover, juveniles presented values of body weight, carapace length, and brain weight significantly lower when compared with those of adult shrimp (Table 1).

\section{DISCUSSION}

The localization and morphology of the OLCM observed in $F$. paulensis brains are in accordance with those described for other penaeid species, including Penaeus monodon (Sheehy et al., 1995), Marsupenaeus japonicus (Medina et al., 2000; Vila et al., 2000) and Parapenaeus longirostris (Ramos et al., 1998; Medina et al., 2000). Although in this particular case, detection of lipofuscin granules in the OLCM using epifluorescence microscopy has been recommended after the age of 5 months for M. japonicus (Vila et al., 2000) and 8 months for P. monodon (Sheehy et al., 1995), our observations for 5-month-old $F$. paulensis indicate that lipofuscin deposition probably takes place even earlier in the juvenile phase.

Lipofuscin accumulates differently during the life span of an individual and can be influenced by environmental factors (Sheehy, 1990; O'Donovan $\&$ Tully, 1996). The granule amount in the OLCM is intimately related to penaeid age independently of sex (Sheehy et al., 1995; Medina et al., 2000; Vila et al., 2000). 
TABLE 1

Mean values ( \pm standard deviation) of body measurements and neural lipofuscin levels in six Farfantepenaeus paulensis adults and juveniles.

\begin{tabular}{|l|c|c|}
\hline & Adult & Juvenile \\
\hline Weight $(\mathrm{g})$ & $32.97 \pm 1.39^{*}$ & $7.34 \pm 0.77$ \\
\hline Carapace length $(\mathrm{mm})$ & $31.60 \pm 6.19^{*}$ & $20.33 \pm 0.95$ \\
\hline Brain weight $(\mathrm{g})$ & $0.028 \pm 0.001^{*}$ & $0.012 \pm 0.001$ \\
\hline Lipofuscin granule diameter $(\mu \mathrm{m})$ & $1.79 \pm 0.36$ & $1.64 \pm 0.32$ \\
\hline Lipofuscin area fraction $(\% \mathrm{OLCM})$ & $0.68 \pm 0.19^{*}$ & $0.24 \pm 0.07$ \\
\hline
\end{tabular}

* Indicates significant differences (Student's t-test, $\alpha=0.05$ ) between treatments.

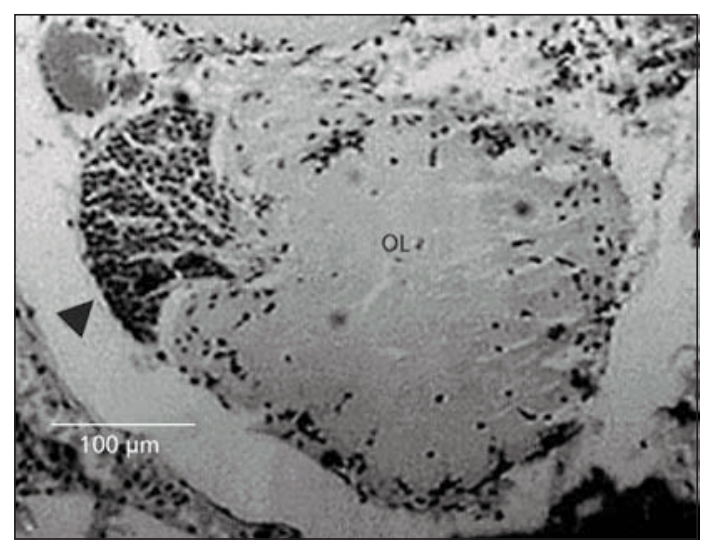

Fig. 2 - Cross section ( $6 \mu \mathrm{m}$ ) of Farfantepenaeus paulensis juvenile brain (5 months old) showing the olfactory lobe (OL) and globuli cell mass (arrowhead) stained with hematoxylin-eosin (200x).
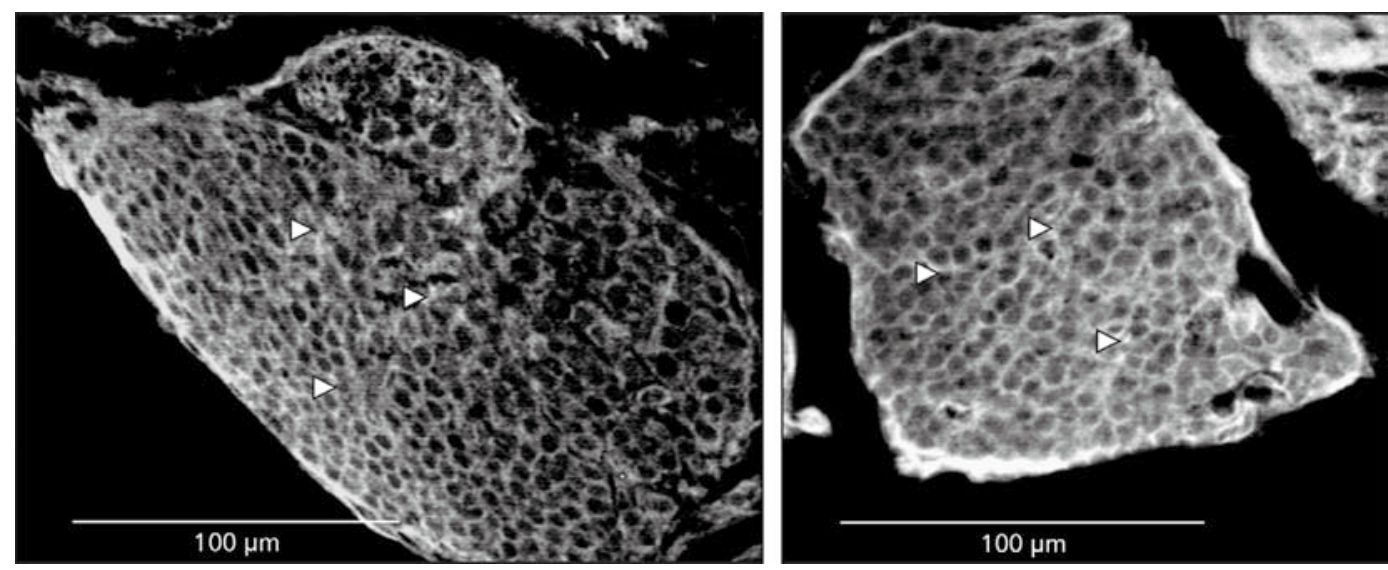

Fig. 3 - Epifluorescence microscopy edited images (400x) of Farfantepenaeus paulensis brain indicating lipofuscin granules (arrowheads) in adults (left) with estimated age of 12-15 months and known-age juveniles (5 months). 
This pattern probably occurs in F. paulensis. However, the area covered by lipofuscin granules (\%OLCM) described by Sheehy et al. (1995) for 15.3-month-old P. monodon ( $0.5 \%)$ was relatively less when compared with adult shrimp in the present study. Nevertheless, the area fractions estimated for $F$. paulensis juveniles $(0.24 \%)$ and adults $(0.68 \%)$ are very similar to those reported for $6.9(0.28 \%)$ and 13.2-month-old $(0.57 \%) M$. japonicus, respectively (Vila et al., 2000).

The accumulation of lipofuscin in the OLCM has been related to increments in granule number rather than their size (Wahle et al., 1996; Vila et al., 2000). The granule diameter in M. japonicus (1.64 to $2.08 \mu \mathrm{m})$ did not present differences among ages varying from 5.5 to 15.2 months (Vila et al., 2000). Accordingly, in the present study no differences were found in the mean granule diameter between $F$. paulensis adults and juveniles.

The method we have used in $F$. paulensis could be useful in fishery management studies done in the Patos Lagoon estuary (D'Incao, 1984) and in the Southern Brazil oceanic population (Zenger \& Agnes, 1977), providing more reliable estimations of cohort ages when lipofuscin quantification results are compared with the length frequency associations adopted in these studies. In addition, since age is an important feature in reproductive performance of wild broodstock in the laboratory (Crocos \& Coman, 1997; Cavalli et al., 1997), lipofuscin quantification could also be applicable in improving broodstock management and larval production.

The first step towards identification and quantification of lipofuscin in $F$. paulensis brains has been taken in the present study. However, in order to fully assess the suitability of this approach as a tool in age estimation, it is essential that a large field study on a captive population of knownage be carried out during the entire life cycle.

\section{REFERENCES}

CAVALLI, R. O., SCARDUA, M. P. \& WASIELESKY, W J., 1997, Reproductive performance of different-sized wild and pond-reared Penaeus paulensis females. J. World Aquac. Soc., 28: 260-267.

CROCOS, P. J. \& COMAN, G. J., 1997, Seasonal and age variability in the reproductive performance of Penaeus semisulcatus: optimising broodstock selection. Aquaculture, 155: 55-67.
BELCHIER, M., SHELTON, P. M. J. \& CHAPMAN, C. J., 1994, The indication and measurement of fluorescent age-pigment abundance in the brain of a crustacean (Nephrops norvegicus) by confocal microscopy. Comp. Biochem Physiol, 108B: 157-164.

DOWSON, J. H. \& HARRIS, S. J., 1981, Quantitative studies of the autofluorescence derived from neuronal lipofuscin. J. Microsc., 123: 249-258.

D'INCAO, F., 1984, Estudos sobre o crescimento de Penaeus (Farfantepenaeus) paulensis Pérez-Farfante, 1967, na Lagoa dos Patos, Rio Grande do Sul, Brasil (Crustacea, Penaeidae). Atlântica, 7: 73-84.

D'INCAO, F. \& FONSECA, D. B., 1998, Performance of the von Bertalanffy growth curve in penaeid shrimps: a critical approach, pp. 733-737. In: Proceedings of the Fourth International Crustacean Congress. Amsterdam, The Netherlands.

GARCIA, S. \& LE RESTE, L., 1981, Life cycles, dynamics exploitation and management of coastal penaeid shrimp stocks. FAO Fish. Technical Paper, 203: 215p.

HILL, K. T. \& WOMERSLEY, C., 1991, Critical aspects of fluorescent age-pigment methodologies modification for accurate analysis and age assessments in aquatic organisms. Mar. Biol., 109: 1-11.

MARCHIORI, M. A., 1996, Guia ilustrado de maturação e larvicultura do camarão-rosa Penaeus paulensis PérezFarafante, 1967. Ed. FURG, Rio Grande, 79p.

MEDINA, A., VILA, Y., MEGINA, C., SOBRINO, I. \& RAMOS, F., 2000, A histological study of the agepigment, lipofuscin, in dendrobranchiate shrimp brains. J. Crust. Biol., 20: 423-430.

O’DONOVAN, V. \& TULLY, O., 1996, Lipofuscin (age pigment) as an index of crustacean age: correlation with age, temperature and body size in cultured juvenile Homarus gammarus. J. Exp. Mar. Biol. Ecol., 207: 1-14

PEIXOTO, S., D'INCAO, F., WASIELESKY, W. J. \& JENSEN, L. V., 2000, Growth and reproduction of captive pink shrimp Farfantepenaeus paulensis, p. 263. In: Proceedings of the Aquaculture America 2000, New Orleans, EUA.

RAMOS, F., SOBRINO, I., VILA, Y., MEGINA, C. \& MEDINA, A., 1998, Identification and quantification of the age-pigment, lipofuscin, in the brain of the deep-water pink-shrimp Parapenaeus longirostris (Lucas, 1876), pp. 345-348. In: Proceedings of the Fourth International Crustacean Congress. Amsterdam, The Netherlands.

ROTHLISBERG, P. C., 1998, Aspects of penaeid biology and ecology of relevance to aquaculture: a review. Aquaculture, 164: 49-65.

SHEEHY, M., 1989, Crustacean brain lipofuscin: an examination of the morphological pigment in the freshwater crayfish Cherax cuspidatus. J. Crust. Biol., 9: 387-391.

SHEEHY, M., 1990, Widespread occurrence of fluorescent morphological lipofuscin in the crustacean brain. $J$. Crust. Biol., 10: 613-622. 
SHEEHY, M., CAMERON, E., MARSDEN, G. \& McGRATH G., 1995, Age structure of female tiger prawns Penaeus monodon as indicated by neuronal lipofuscin concentration. Mar. Ecol. Prog. Ser., 117: 59-63.

VILA, Y., MEDINA, A., MEGINA, C., RAMOS, F. \& SOBRINO, I., 2000, Quantification of the age-pigment lipofuscin in brains of known-age, pond-reared prawns Penaeus japonicus (Crustacea, Decapoda). J. Exp. Zool., 286: $120-130$
WAHLE, R. A., TULLY, O. \& O'DONOVAN, V., 1996, Lipofuscin as an indicator of age in crustaceans: analysis of the pigment in the American lobster Homarus americanus. Mar. Ecol. Prog. Ser., 138: 117-123.

ZENGER, H. H. \& AGNES, J. L., 1977, Distribuição do camarão-rosa (Penaeus brasiliensis e Penaeus paulensis) ao longo da costa sudeste e sul do Brasil. Série Documentos Técnicos, SUDEPE-PDP, 21: 1-105. 